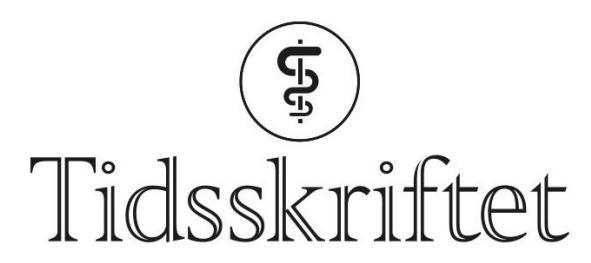

DEN NORSKE LEGEFORENING

\title{
Farlig furting
}

MINILEDER

RAGNHILD ØRSTAVIK

Assisterende sjefredaktør

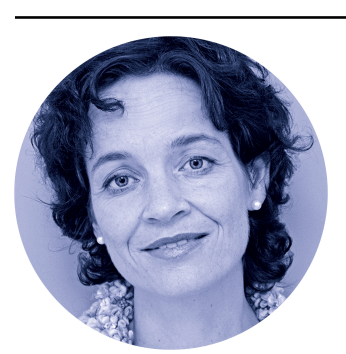

I 1949 meldte Sovjetunionen og flere andre østblokkland seg ut av Verdens helseorganisasjon (WHO). De mente at USA tok for stor plass og at organisasjonen motarbeidet den sosialistiske ideologien. Først etter Stalins død meldte landene seg inn igjen.

Nå gjør USAs president det samme. Trump varslet i mai om at USA ville trekke seg fra WHO, fordi Kina har fått for mye innflytelse og fordi håndteringen av covid-19-pandemien har vært for svak og for lukket. Tross advarsler fra landets helsepersonell, jurister og spesialister $\mathrm{i}$ internasjonalt samarbeid sendte han 6. juli en offisiell henvendelse til FNs generalsekretær om utmelding.

Men det er ikke bare å smelle døren furtent igjen etter seg. Det er uklart om en reell utmelding er juridisk mulig. Uansett kreves det et års forvarsel, og alle planlagte donasjoner skal betales innen utløpet av det siste året. Det tidligste USA kan være utmeldt, er altså i juli 2021. Det gir et håp for alle som ønsker et lederskifte i november, for WHO som kan miste sin største bidragsyter, og for verdens helse som knapt kan få en verre medisin enn manglende samarbeidsvilje mellom stormaktene.

Publisert: 17. august 2020. Tidsskr Nor Legeforen. DOI:10.4045/tidsskr.20.11.01

(C) Tidsskrift for Den norske legeforening 2020. Lastet ned fra tidsskriftet.no 